\title{
TINGKAT STRES DENGAN KADAR GULA DARAH PADA PASIEN DIABETES MELITUS
}

\author{
STRESS LEVELS WITH BLOOD SUGAR LEVELS IN DIABETES MELLITUS \\ PATIENTS
}

\author{
Lusiana Adam, Mansyur B. Tomayahu \\ Program Studi Keperawatan \\ Politeknik Kesehatan Gorontalo \\ lusiana.adam@yahoo.com
}

\begin{abstract}
Abstrak
Diabetes melitus merupakan penyakit gangguan metabolisme kronis yang ditandai peningkatan glukosa darah (hiperglikemi) disebabkan karena ketidakseimbangan antara suplai dan kebutuhan untuk memfasilitasi masuknya glukosa dalam sel agar dapat di gunakan untuk metabolisme dan pertumbuhan sel. Stres dan Diabetes Melitus memiliki hubungan yang sangat erat, dimana tingkat stres yang tinggi dapat memicu kadar gula darah seseorang semakin meningkat. Penelitian ini bertujuan untuk mengetahui hubungan tingkat stres dengan peningkatan kadar gula darah pada pasien Diabetes Melitus di Puskesmas Kota Barat Kota Gorontalo. Desain penelitian ini menggunakan pendekatan cross sectional study. Populasinya adalah seluruh pasien Diabetes Melitus yang berada di wilayah kerja Puskesmas Kota Barat Kota Gorontalo. Jumlah Sampel 52 orang yang diambil dengan proporsional sampling. Hasil penelitian menunjukkan bahwa ada hubungan yang signifikan antara tingkat stres dengan peningkatan kadar gula darah pada pasien Diabetes Melitus di Puskesmas Kota Barat Kota Gorontalo tahun 2018 dengan $\mathrm{P}=0,000<\alpha=0,01$.
\end{abstract}

Kata Kunci: Tingkat Stres, Kadar Glukosa Darah, Diabetes Melitus

\begin{abstract}
Diabetes Mellitus is a chronic metabolic disorder characterized by an increase in blood glucose (hyperglycemia) caused by an imbalance between supply and the need to facilitate the entry of glucose in cells so that it can be used for metabolism and cell growth. Stress and Diabetes Mellitus have a very close relationship, where high levels of stress can trigger a person's blood sugar levels to increase. This study aims to determine the relationship of stress levels with an increase in blood sugar levels in patients with diabetes mellitus in the City West Health Center of Gorontalo City. The design of this study used a cross-sectional study approach. The population is all Diabetes Mellitus patients in the working area of Kota Barat Health Center, Kota Gorontalo. The total sample was 52 people taken by proportional sampling. The results showed that there was a significant relationship between stress levels and an increase in blood sugar levels in patients with Diabetes Mellitus in the Kota Barat Health Center of Gorontalo City in 2018 with $P=0,000 \alpha \alpha=0.01$.
\end{abstract}

Keywords: Stress Levels, Blood Glucose Levels, Diabetes Mellitus. 


\section{Pendahuluan}

Diabetes Melitus merupakan penyakit gangguan metabolisme kronis yang ditandai peningkatan glukosa darah (Hiperglikemi), disebabkan karena ketidakseimbangan antara suplai dan kebutuhan untuk memfasilitasi masuknya glukosa dalam sel agar dapat digunakan untuk metabolisme dan pertumbuhan sel. Berkurang atau tidak adanya insulin menjadikan glukosa tertahan di dalam darah dan menimbulkan peningkatan gula darah, sementara sel menjadi kekurangan glukosa yang sangat dibutuhkan dalam kelangsungan dan fungsi sel (Izzati \& Nirmala, 2015).

Diabetes Melitus terbagi menjadi 2 tipe yaitu tipe I dan tipe II. Individu yang menderita Diabetes Melitus tipe I memerlukan suplai insulin dari luar (eksogen insulin), seperti injeksi untuk mempertahankan hidup. Tanpa insulin pasien akan mengalami diabetic ketoasidosis, kondisi yang mengancam kehidupan yang di hasilkan dari asidosis metabolik. Individu dengan Diabetes Melitus tipe II resisten terhadap insulin, suatu kondisi dimana tubuh atau jaringan tubuh tidak berespon terhadap aksi dari insulin. Sehingga individu tersebut hanya selalu menjaga pola makan, mencegah terjadinya hipoglikemi atau hiperglikemi dan hal tersebut akan berlangsung secara menerus sepanjang hidupnya (Izzati \& Nirmala 2015).

World Health Organitation (WHO) memprediksi adanya peningkatan jumlah penyandang diabetes yang cukup besar pada tahun-tahun mendatang. WHO memprediksi kenaikan jumlah penyandang DM di Indonesia dari 8,4 juta pada tahun 2000 menjadi sekitar 21,3 juta pada tahun 2030 . Senada dengan WHO, Internasional Diabetes Federation (IDF) pada tahun 2009, memprediksi kenaikan jumlah penyandang DM dari 7,0 juta pada tahun 2009 menjadi 12,0 juta pada tahun 2030. Menurut WHO, saat ini Indonesia menempati urutan ke-4 terbesar dalam jumlah penderita diabetes Melitus di dunia.

Pada tahun 2006 jumlah Diabetisi di Indonesia diperkirakan mencapai 14 juta orang, dimana baru $50 \%$ yang sadar mengidapnya dan diantara mereka baru sekitar $30 \%$ yang datang berobat teratur (Pratiwi dkk, 2014).

Hasil Riset Kesehatan Dasar (Riskesdas) tahun (2013), Menunjukkan bahwa prevalensi diabetes yang terdiagnosis dokter tertinggi terdapat di DI Yogyakarta $(2,6 \%)$, DKI Jakarta $(2,5 \%)$, Sulawesi Utara $(2,4 \%)$ dan Kalimantan Timur (2,3\%). Prevalensi diabetes yang terdiagnosis dokter atau gejala, tertinggi terdapat di Sulawesi Tengah $(3,7 \%)$, Sulawesi Utara $(3,6 \%)$, Sulawesi Selatan $(3,4 \%)$ dan Nusa Tenggara Timur 3,3 persen.

Hasil Riskerdas Provinsi Gorontalo tahun 2013, Prevalensi Diabetes hasil diagnosis oleh tenaga kesehatan dan gejala (DG) adalah sebanyak 1,3\% dan prevalensi tertinggi ditemukan di Kabupaten Boalemo $(3,2 \%)$. Sedangkan prevalensi DM berdasarkan diagnosis oleh tenaga kesehatan sebesar 0,5\%. Data ini menunjukkan cakupan diagnosis DM oleh tenaga kesehatan mencapai 38,5\%, lebih tinggi dibandingkan cakupan penyakit asma maupun penyakit jantung. Prevalensi penyakit Jantung dan Diabetes, menurut diagnosis tenaga kesehatan, tertinggi ditemukan di Kota Gorontalo sebesar 4,0\%.

Berdasarkan data Dinas Kesehatan Kota Gorontalo jumlah penderita Diabetes Melitus pada tahun 2016 pada kasus lama sejumlah 1.982 jiwa dan pada kasus baru ditemukan dengan jumlah 888 jiwa. Sedangkan pada tahun 2017 pada kasus lama sejumlah 1.650 dan kasus lama sejumlah 984 jiwa.

Berdasarkan hasil studi pendahuluan jumlah penderita Diabetes Melitus di Puskemas Kota Barat Kota Gorontalo yang tercatat pada tahun 2016 berjumlah 46 jiwa, tahun 2017 berjumlah 111 jiwa, sedangkan yang tercatat pada bulan Februari tahun 2018 berjumlah 110 jiwa.

Meningkatnya jumlah penderita Diabetes Melitus dapat disebabkan oleh banyak faktor, antara lain adalah faktor keturunan/genetik, obesitas, perubahan gaya hidup, pola makan yang salah, obat-obatan yang mempengaruhi kadar glukosa darah, kurangnya aktivitas fisik, proses menua, kehamilan, perokok dan stres (Meivy dkk, 2017). Kondisi ini dapat menimbulkan 
berbagai perubahan atau gangguan baik fisik maupun psikologis bagi pasien. Pasien Diabetes harus tergantung pada terapi pengelolaan diabetes. Hal tersebut dapat menimbulkan permasalahan misalnya pasien merasa lemah kerena harus membatasi diet, setiap perubahan dalam kesehatan dapat menjadi stressor. Keharusan pasien Diabetes Melitus mengubah pola hidupnya agar gula darah dalam tubuh tetap seimbang dapat mengakibatkan mereka rentan terhadap stres, karena stres akan terjadi apabila seseorang merasakan adanya ketidaksesuaian antara sumber daya yang dimiliki dengan tuntutan situasi yang harus dijalankan ketika tuntutan situasi dirasakan berbeda dangan situasi sebelumnya dan terlalu berat maka stres akan terjadi (Izzati \& Nirmala, 2015).

Stres adalah respon tubuh yang tidak spesifik terhadap setiap kebutuhan yang terganggu, suatu fenomena universal yang terjadi dalam kehidupan sehari-hari dan tidak dapat dihindari, setiap orang mengalaminya, stres memberi dampak secara total pada individu yaitu terhadap fisik, psikologis, intelektual, sosial dan spiritual, stres dapat mengancam kesimbangan fisiologis (Meivy dkk, 2017). Tingkat stres yang tinggi dapat memicu kadar gula darah seseorang semakin meningkat, sehingga semakin tinggi tingkat stres yang dialami oleh pasien Diabetes, maka penyakit Diabetes Melitus yang diderita akan semakin tambah buruk (Izzati \& Nirmala, 2015).

Stres dan Diabetes Melitus memiliki hubungan yang sangat erat terutama pada penduduk perkotaan. Tekanan kehidupan dan gaya hidup tidak sehat sangat berpengaruh, ditambah dengan kemajuan teknologi yang semakin pesat dan berbagai penyakit yang sedang diderita menyebabkan penurunan kondisi seseorang sehingga memicu terjadinya stres (Meivy dkk, 2017).

Berdasarkan uraian diatas maka peneliti tertarik meneliti "Hubungan Tingkat Stres Dengan Peningkatan Kadar Gula Darah Pada Pasien Diabetes Melitus di Puskesmas Kota Barat Kota Gorontalo.

\section{Metode Penelitian}

Desain penelitian ini menggunakan pendekatan cross sectional study, semua data yang dibutuhkan dikumpulkan dalam satu waktu (Singarimbun \& Effendi, 2008).

\section{Metode Pengumpulan Data}

Pengumpulan data dengan menggunakan data primer berupa wawancara langsung dengan menggunakan kuesioner untuk mengukur tingkat stres dan formulir lembar observasi, dan alat pengukuran gula darah (glukotest). Penarikan sampel dari penelitian ini diambil dengan proportional sampling, yakni sebanyak 52 orang dengan kriteria inklusi: Bersedia menjadi responden, pasien yang menderita Diabetes Melitus, tidak memiliki penyakit komplikasi, tidak menggunakan suntikan insulin.

\section{Analisis Data}

Pengolahan data dilakukan secara manual dan elektronik dengan menggunakan kalkulator dan komputerisasi dengan program pengolahan data statistik, dengan langkah-langkah sebagai berikut: editing, coding, entry data dan cleaning data.

\section{Hasil Penelitian}

Berdasarkan hasil pengukuran tingkat stres melalui lembar kuisioner, dan pengukuran kadar gula darah, maka didapatkan hasil sebagai berikut:

1. Terdapat 32 responden $(61,5 \%)$ yang mengalami peningkatan kadar gula darah dengan kategori buruk, 13 responden ( 25 $\%)$ yang mengalami peningkatan kadar gula darah dengan kategori sedang dan 7 responden $(13,5 \%)$ yang kadar gula darahnya dalam kategori baik.

2. Adapun untuk pengukuran tingkatan stres yang dialami oleh responden yakni sebanyak 9 responden $(17,3 \%)$ yang mengalami kategori stres berat, 38 responden $(73,1 \%)$ yang mengalami kategori stres sedang, sedangkan kategori stres ringan sebanyak 5 responden $(9,6 \%)$.

\section{Pembahasan}

Hasil penelitian ini menunjukkan bahwa sebagian besar responden mengalami 
stres sedang yakni sebanyak 38 orang. Tingkat stres yang terjadi pada responden disebabkan oleh faktor usia, dimana sebagian besar penderita Diabetes Melitus di Puskesmas Kota Barat Kota Gorontalo berusia $>50$ tahun sebanyak 33 orang. Peneliti berasumsi saat seseorang sudah berlanjut usia akan terjadi perubahan fisik dan mental, seperti mudah terserang penyakit fisik dan mudah stres yang disertai dengan sering merasa cemas, merasa tidak berguna lagi, pola tidur tidak teratur dan aktivitas yang terganggu namun responden masih bisa di kontrol karena ada motivasi untuk sembuh dan selalu didukung oleh keluarga.

Hasil penelitian ini sejalan dengan penelitian yang di lakukan oleh Izzati \& Nirmala (2015) tentang hubungan tingkat stres dengan kadar gula darah pada pasien diabetes melitus tipe II di Bukittinggi, di dapatkan hasil dari 32 responden terdapat lebih dari separuh responden mengalami stres sedang sebanyak 20 orang $(62,5 \%)$. Kondisi ini disebabkan oleh adanya semangat hidup dalam diri responden, yang juga diikuti dengan keimanannya bahwa setiap penyakit itu ada obatnya.

Berdasarkan hasil penelitian didapatkan bahwa distribusi responden berdasarkan kadar gula darah di Puskesmas Kota Barat Kota Gorontalo yakni kadar gula darah dengan kategori baik sebanyak 7 orang (13,5\%), kategori sedang sebanyak 13 orang $(25 \%)$, dan kategori buruk sebanyak 32 orang $(61,5 \%)$. Dari hasil penelitian ini didapatkan lebih banyak responden dengan kadar gula darah buruk. Menurut peneliti kadar gula darah responden yang sebagian besar buruk dikarenakan beberapa faktor yaitu stres, pola makan yang tidak teratur (diet), lupa minum obat dan kurangnya berolahraga. Selain itu, faktor umur juga bisa mempengaruhi kadar gula darah responden dimana paling banyak responden dengan umur $>50$ tahun. Darmayanti (2015) memaparkan bahwa faktor risiko menyandang Diabetes Melitus II adalah usia diatas 30 tahun, hal ini karena adanya penurunan anatomis, fisiologis, dan biokimia. Perubahan dimulai Dari tingkat sel, kemudian berlanjut pada tingkat jaringan dan akhirnya pada tingkat organ yang dapat mempengaruhi homeostatis.

Hasil penelitian ini sejalan dengan penelitian yang dilakukan oleh Meivy dkk (2017) tentang hubungan tingkat stres dengan kadar gula darah pada pasien diabetes melitus tipe II di Rumah Sakit Pancaran Kasih GMIM Manado, dimana dari 75 responden terdapat separuh responden dengan kadar gula darah buruk sebanyak 39 orang $(52,0 \%)$. Kondisi ini disebabkan oleh beberapa faktor diantaranya pola makan.

Berdasarkan hasil penelitian yang didapatkan bahwa dari 52 responden di Puskesmas Kota Barat Kota Gorontalo, maka dapat diketahui bahwa terdapat 5 orang $(9,6 \%)$ yang mengalami stres ringan dengan kadar gula darah yang baik. Terdapat 38 orang $(73,1 \%)$ yang mengalami stres sedang. dari jumlah tersebut sebanyak 2 orang $(3,8 \%)$ dengan kadar gula darah baik, 13 orang $(25 \%)$ dengan kadar gula darah sedang, 23 orang $(44,2 \%)$ dengan kadar gula darah buruk. Terdapat 9 orang $(17,3 \%)$ yang mengalami stres berat dan kadar gula darah yang buruk. Berdasarkan hasil uji Spearmen Rank, didapatkan nilai $\mathrm{p}$ value $=0,000$ dan $\alpha=0,01$ dimana 0,000 lebih kecil dari $0,01(\mathrm{p}<\alpha)$ yang berarti $\mathrm{H}_{0}$ ditolak dan $\mathrm{H}_{\mathrm{a}}$ diterima, maka dapat dikatakan adahubungan yang signifikan antara tingkat stres dengan peningkatan kadar gula darah pada pasien diabetes melitus di Puskesmas Kota Barat Kota Gorontalo tahun 2018.

Peneliti berasumsi bahwa responden dengan tingkat stres buruk sangat berpeluang untuk mengalami peningkatan kadar gula darah dibandingkan stres sedang. Kemudian responden dengan tingkat stres sedang namun memilikikadar gula darah buruk, hal ini disebabkan oleh faktor lain yaitu responden belum bisa mengontrol kadar gula darah dengan cara belum bisa mengatur pola makan, meminum obat tidak teratur, dan kurang beraktivitas. Sehingga kadar gula darahnya akan tetap meningkat, walaupun tingkat stres yang dialami dalam kategori sedang. Sedangkan responden dengan tingkat stres sedang dan kadar gula darah baik karena mereka tetap bisa mengatur pola makan dan meminum obat 
secara teratur meskipun dalam keadaan stres.

Meningkatnya jumlah penderita Diabetes Melitus dapat disebabkan oleh banyak faktor, antara lain adalah faktor keturunan/genetik, obesitas, perubahan gaya hidup, pola makan yang salah, obat-obatan yang mempengaruhi kadar glukosa darah, kurangnya aktivitas fisik, proses menua, kehamilan, perokok dan stress (Meivy dkk, 2017).

Kondisi ini dapat menimbulkan berbagai perubahan atau gangguan baik fisik maupun psikolosis bagi pasien. Hal tersebut dapat menimbulkan permasalahan misalnya pasien merasa lemah kerena harus membatasi diet, setiap perubahan dalam kesehatan dapat menjadi stresor. Keharusan pasien Diabetes Melitus mengubah pola hidupnya agar gula darah dalam tubuh tetap seimbang dapat mengakibatkan mereka rentan terhadap stres, karena stres akan terjadi apabila seseorang merasakan adanya ketidaksesuaian antara sumber daya yang dimiliki dengan tuntutan situasi yang harus dijalankan ketika tuntutan situasi dirasakan berbeda dangan situasi sebelumnya dan terlalu berat maka stres akan terjadi (Izzati \& Nirmala, 2015).

Stres dapat meningkatkan kandungan glukosa darah karena stres menstimulus organ endokrin untuk mengeluarkan ephinefrin, ephinefrin mempunyai efek yang sangat kuat dalam menyebabkan timbulnya proses glikoneogenesis di dalam hati, sehingga akan melepaskan sejumlah besar glukosa ke dalam darah dalam beberapa menit. Hal inilah menyebabkan peningkatan kadar glukosa darah saat stres atau tegang. Beberapa hal yang menyebabkan gula darah naik, yaitu kurang berolah raga, bertambahnya jumlah makanan yang dikonsumsi, meningkatnya stres dan faktor emosi, pertambahan berat badan dan usia, serta dampak perawatan dari obat, misalnya steroid (Pratiwi dkk, 2014).

Hal ini sesuai dengan penelitian yang dilakukan oleh Izzati \& Nirmala (2015), yang menyimpulkan bahwa terdapat hubungan antara tingkat stres dengan peningkatan kadar gula darah pada pasien Diabetes Melitus di wilayah kerja
Puskesmas Perkotaan Rasimah Ahmad Bukittinggi $(\mathrm{p}=0,017)$.

\section{Kesimpulan}

Kesimpulan dari penelitian ini adalah terdapat hubungan yang positif tingkat stres dengan peningkatan kadar gula darah pada pasien Diabetes Melitus di Puskesmas Kota Barat Kota Gorontalo.

\section{Daftar Pustaka}

Izzati, W \& Nirmala, 2015. Hubungan Tingkat Stres Dengan Peningkatan Kadar Gula Darah Pada Pasien Diabetes Melitus Di Wilayah Kerja Puskesmas Perkotaan Rasimah Ahmad Bukittinggi Tahun 2015 (diakses tanggal 12 Februari 2018)

Kemenkes. 2013. Riset Kesehatan Dasar:

Riskesdas 2013. Jakarta: Badan

Penelitian dan Pengembangan Kesehatan Kementrian Kesehatan RI.

Meivy dkk, 2017. Hubungan Tingkat Stres

Dengan Kadar Gula Darah Pada Pasien Diabetes Melitus Tipe II di Rumah Sakit Pancaran Kasih GIMM Manado (diakses tanggal 13 Februari 2018)

Pratiwi, P. dkk, 2014, Pengaruh Stres Terhadap Kadar Gula Darah Sewaktu Pada Pasien Diabetes Melitus yang Menjalani Hemodialisa di RSUD dr. H. Abdoel Moeloek Bandar Lampung (diakses tanggal 13 Februari 2018)

Singarimbun, M \& Effendi, S. 2008. Metode Penelitian Survei. LP3ES: Jakarta 